\title{
PENGARUH SISTEM INFORMASI ADMINISTRASI KEPENDUDUKAN (SIAK) TERHADAP EFEKTIVITAS KERJA PEGAWAI PADAKANTOR DINAS KEPENDUDUKAN DAN PENCATATAN SIPIL KABUPATEN BOGOR
}

\author{
Dasmansyah Adyas \\ STIE DEWANTARA \\ dasmansyah53@gmail.com \\ Lensie D. Anggeraiyantie \\ STIE DEWANTARA \\ Diterima 27 Maret 2018, Disetujui 02 April 2018
}

\begin{abstract}
Abstrak
Penelitian ini bertujuan untuk mengetahui: pengaruh variabel bebas yaitu Sistem Informasi Administrasi Kependudukan (SIAK) yang terdiri dari (sesuai prosedur, memiliki standar khusus, dan tertib administrasi) secara parsial dan simultan terhadap variabel terikat yaitu Efektivitas Kerja Pegawai pada Dinas Kependudukan dan Pencatatan Sipil Kabupaten Bogor. Populasi dalam penelitian ini adalah pegawai yang menggunakan aplikasi sistem informasi administrasi kependudukan (SIAK), dengan sampel sebanyak 45 pegawai dengan menggunakan teknik Sampling Jenuh yaitu teknik penentuan sampel bila semua anggota populasi digunakan sebagai sampel. Metode analisis menggunakan analisis regresi berganda. Dari hasil penelitian didapatkan persamaan regresi, menunjukkan nilai yang positif. Hasil uji hipotesis untuk pengujian secara parsial (uji t) menunjukkan hasil bahwa ketika variabel bebas secara sendiri-sendiri tidak ada pengaruh terhadap variabel terikat. Sedangkan secara simultan ketiga variabel bebas tersebut mempunyai pengaruh terhadap variabel terikat. Dari hasil uji koefisien determinasi nilai Adjusted $R$ Square yang diperoleh sebesar 0,320 (32\%), sedangkan sisanya 68\% dipengaruhi oleh faktor lain yang tidak diteliti dalam penelitian ini.
\end{abstract}

Kata Kunci : Sesuai, Prosedur, Memiliki, Standar, Khusus, Tertib, Administrasi,dan Efektivitas, Kerja, Pegawai.

\section{Abstract}

This study aims to determine: the influence of independent variables is Information Systems Administration Population (SIAK) which consists of (according to procedures, have special standards, and orderly administration) partially and simultaneously to the dependent variable of Employee Effectiveness on the Department of Population and Civil Registry Bogor. Population in this research is employee who use application of information system of administration of population (SIAK), with sample of 45 employee by using Sampling Saturation technique that is sample determination technique when all member of population used as sample. The method of analysis using multiple regression analysis. From the research results obtained regression equation, shows a positive value. The hypothesis test result for partial test (t test) shows that when independent variables independently there is no influence on the dependent variable. While the three independent variables have an influence on the dependent variable. From result of determination coefficient test of Adjusted R Square value obtained by 0,320 (32\%), while the rest $68 \%$ influenced by other factor not examined in this research.

Keywords: Appropriate, Procedures, Have, Standards, Special, Orderly, Administration, and Effectiveness, Employment, Employees. 


\section{PENDAHULUAN}

Globalisasi informasi atau globalisasi digital ditandai dengan munculnya teknologi dan sistem informasi, sebagai konsekuansinya setiap unit pekerjaan kantor harus menyesuaikan diri menggunakan bantuan komputer agar dapat meningkatkan efektivitas kerja. Efektivitas merupakan unsur pokok dalam mencapai tujuan atau sasaran yang telah ditentukan tepat pada waktunya dengan menggunakan sumber-sumber tertentu yang telah dialokasikan untuk melakukan berbagai kegiatan (Siagian, 2000:171). Suatu pekerjaan dapat dikatakan efektif apabila hasil yang dicapai telah sesuai dengan tujuan yang telah ditetapkan yaitu tepat sasaran dan tepat waktu.. Secara sederhana efektivitas kerja dapat didefinisikan sebagai kemampuan melakukan sesuatu tepat sasaran (doing the right things). Dengan menggunakan system informasi diharapkan kinerja pegawai akan semakin efektif untuk mencapai tujuan organisasi, khususnya dikalangan organisasi pemerintahan..

Berdasarkan Undang-undang Nomor 24 Tahun 2013 tentang perubahan atas Undang-Undang Nomor 23 tahun 2006 Tentang Administrasi Kependudukan dijelaskan bahwa instansi pelaksana administrasi kependudukan untuk wilayah kabupaten/ kota adalah Dinas Kependudukan dan Pencatatan Sipil. Dinas ini yang berwenang memberikan pelayanan yang sama dan profesional kepada setiap penduduk atas pelaporan peristiwa kependudukan dan peristiwa penting kependudukkan lainnya. Penyelenggaraan administrasi kependudukan, peristiwa penting kependudukan yang meliputi kelahiran, kematian, perkawinan, perceraian, pengakuan anak, pengesahan anak dan lain-lain yang harus di catat ke dalam pencatatan sipil harus didata dengan sebaik-baiknya sebagai bentuk pelayanan publik kepada masyarakat.

Berkenaan dengan hal tersebut untuk mempermudah penyelenggaraan administrasi kependudukan dalam melakukan pengumpulan, pengolahan data penduduk yang berbasis teknologi informasi, Pemerintah Pusat dalam hal ini telah menyiapkan suatu sistem yang diberi nama "Sistem Informasi Administrasi Kependudukan” atau disingkat SIAK. Yang merupakan suatu sistem informasi berbasis web yang disusun berdasarkan prosedur-prosedur dan memakai standarisasi khusus yang bertujuan menata sistem administrasi dibidang kependudukan sehingga tercapai tertib administrasi dan juga membantu bagi petugas dijajaran. Pemerintah Daerah khususnya Dinas Kependudukan didalam menyelenggarakan layanan kependudukan. Dalam SIAK terdapat tiga komponen yang saling terkait dan saling komplementer yaitu pendaftaran penduduk, pencatatan sipil dan pengolahan informasi. (Rizky Nugraha, 2014:2)

Dalam rangka pencapaian efektivitas, ada berbagai kendala yang dihadapi oleh para pegawai dalam pelaksanaan pekerjaannya yang tidak mendukung terciptanya efektivitas tersebut, misalnya pendaftaran penduduk dan pencatatan sipil yang berupa data/ laporan belum dapat secara maksimal digunakan untuk kepentingan pelayanan publik, banyak sekali peristiwa seperti kelahiran, perkawinan, dan lainnya belum didata secara benar. Begitu juga masalah kependudukan, seperti pindah datang belum didata secara baik, bahkan penduduk masih banyak yang belum memiliki dokumen kependudukan. Dan beragamnya tugas yang terhimpun yang menyebabkan lambatnya penyelesaian masingmasing tugas tersebut, disamping itu juga terdapat kurangnya sarana dan prasarana yang mendukung dalam pelaksanaan pekerjaan.

SIAK bisa menjadi solusi dari masalah kependudukan yang ada. SIAK sendiri memberikan banyak manfaat antara lain, tercapainya tertib administrasi kependudukan, karena dengan adanya NIK maka permasalahan seperti KTP ganda tidak akan terjadi, tercapainya efisiensi dan efektifitas dalam layanan publik dan untuk pengolahan data baik yang berhubungan dengan peristiwa penting (lahir, mati, kawin, cerai dan lain-lain) maupun peristiwa kependudukan (perubahan alamat, pindah datang dan perpanjangan KTP). SIAK dirancang, dibangun dan dikembangkan untuk mampu menyelenggarakan penerbitan NIK Nasional sebagai nomor identitas tunggal yang ditampilkan pada setiap dokumen kependudukan, sebagai kunci akses untuk verifikasi data diri maupun identifikasi jati diri seseorang, dengan SIAK maka pengolahan data akan lebih mudah dan efisien, sehingga tidak mengakibatkan lambatnya pembuatan surat-surat pengurusan biodata penduduk.

\section{Tujuan Penelitian}

Penelitian ini bertujuan untuk mengetahui tentang: (1) Apakah variabel-variabel sistem informasi administrasi kependudukan (SIAK) secara parsial berpengaruh terhadap efektivitas kerja pegawai pada Kantor Dinas Kependudukan dan Pencatatan Sipil Kabupaten Bogor?; (2) Apakah variabel-variabel sistem informasi administrasi kependudukan (SIAK) secara simultan berpengaruh terhadap efektivitas 
kerja pegawai pada Kantor Dinas Kependudukan dan Pencatatan Sipil Kabupaten Bogor?; (3) Variabel bebas manakah yang memiliki pengaruh dominan terhadap Efektivitas Kerja Pegawai pada Kantor Dinas Kependudukan dan Pencatatan Sipil Kabupaten Bogor?.

\section{KAJIAN TEORI}

\section{Pengertian Sistem Informasi Administrasi Kependudukan (SIAK)}

Menurut Undang-Undang No. 23 Tahun 2006 Pengertian Sistem Informasi Administrasi Kependudukan (SIAK) adalah sistem informasi yang memanfaatkan teknologi informasi dan komunikasi untuk memfasilitasi pengelolaan informasi administrasi kependudukan di tingkat penyelenggraan dan instansi pelaksanaan sebagai satu kesatuan.

Definisi lain dari Sistem Informasi Administrasi Kependudukan yaitu suatu sistem berbasis web yang disusun berdasarkan prosedur-prosedur dan memakai standarisasi khusus yang bertujuan menata sistem administrasi kependudukan sehingga tercapai tertib administrasi dibidang kependudukan dan juga membantu bagi petugas dijajaran pemerintah daerah, khususnya Dinas Kependudukan dalam menyelenggarakan layanan kependudukan. Dalam implementasinya, SIAK menerapkan Nomor Induk Kependudukan (NIK) sebagai induk dari data kependudukan yang merupakan nomor identitas penduduk yang bersifat unik atau khas, tunggal dan melekat pada seseorang yang terdaftar sebagai penduduk Indonesia, yang berlaku selamanya. Dalam SIAK, database antara kecamatan, kabupaten-kota, provinsi dan Departemen Dalam Negeri (DEPAGRI) akan terhubung dan terintegrasi. Seseorang tidak bisa memiliki identitas ganda dengan adanya Nomor Identitas Kependudukan (NIK). Sebab, nomor bersifat unik dan akan keluar secara otomatis ketika instansi pelaksana memasukkannya ke database kependudukan (Rizky Nugraha, 2014:2).

\section{Peranan SIAK dalam Administrasi Kependudukan}

Sistem Informasi Administrasi Kependudukan mempunyai peranan antara lain (Rizky Nugraha, 2014 :5) 1). Perekaman, pengiriman dan pengolahan data hasil pendaftaran penduduk dan pencatatan sipil. 2). Penerbitan NIK Nasional. 3). Memfasilitasi validasi dan verifikasi individu pendudukan untuk pelayanan publik lainnya. 4). Penyajian data dan informasi yang mutakhir bagi instansi terkait dalam rangka perencanaan pembangunan dan pelaksanaan program pemerintah. Manfaat Sistem Informasi Administrasi Kependudukan, pada dasarnya system informasi kependudukan akan banyak memberi manfaat bagi penduduk Indonesia terutama dalam tertib administrasi kependudukan, terhindarnya masyarakat dari pengeluaran biaya yang tidak ada hubungan dengan urusan administrasi penduduk. Sedangkan bagi aparat pemerintah tercapainya good governance dalam public service, karena layanan yang dilakukan aparat pemerintahan daerah berjalan dengan sangat efektif dan efisien. Siak juga akan menghimpun data individu penduduk (mikro) dan data agregat (makro) penduduk. Penyediaan data tersebut melalui pengembangan SIAK dengan membangun Bank Data Kependudukan Nasional. Bank data kependudukan ini menyimpan data kependudukan secara nasional, yang dapat menyajikan berbagai profil kependudukan untuk kepentingan individu, masyarakat, pemerintah, dan kepentingan pembangunan lainnya. Untukpengolahan data statistik vital (vital statistic) baik yang berhubungan dengan peristiwa penting (lahir, mati, kawin, cerai dan lain-lain) maupun peristiwa kependudukan (perubahan alamat, pindah datang dan perpanjangan KTP). Hasil perhitungan dan pengolahan data statistik tersebut sebagai bahan perumusan dan penyempurnaan kebijakan, strategi dan program bagi para penyelenggara dan pelaksana pembangunan dibidang kualitas, kuantitas, dan mobilitas penduduk, serta kepentingan pembangunan lainnya. (Nugraha,2014:6) Tujuan Sistem Informasi Administrasi Kependudukan Menurut Peraturan Pemerintah Nomor 37 Tahun 2007 tentang Pelaksanaan Undang-Undang Nomor 23 Tahun 2006 tentang Administrasi Kependudukan, pengelolaan SIAK bertujuan: Meningkatkan kualitas pelayanan Pendaftaran Penduduk dan Pencatatan Sipil, Menyediakan data dan informasi skala nasional dan daerah mengenai hasil pendaftaran penduduk dan pencatatan sipil yang akurat, lengkap, mutakhir dan mudah diakses, Mewujudkan pertukaran data secara sistemik melalui sistem pengenal tunggal, dengan tetap menjamin kerahasiaan.

\section{Unsur-Unsur Sistem Informasi Administrasi Kependudukan:}

Menurut Peraturan Pemerintah Republik Indonesia Nomor 102 Tahun 2012 tentang Perubahan atas Peraturan Pemerintah Nomor 37 Tahun 2007 tentang Pelaksanaan Undang-Undang Nomor 23 Tahun 2006 tentang Administrasi Kependudukan, 
SIAK merupakan satu kesatuan kegiatan terdiri dari unsur: Database, Perangkat teknologi informasi dan komunikasi, Sumber daya manusia, Pemegang hak akses, Lokasi database, Pengelolaan database, Pemeliharaan database, Pengamanan database, Pengawasan database, Data cadangan (back-up data/disaster recovery centre), Perangkat pendukung, Tempat pelayanan, Pusat data, Pusat data cadangan, Jaringan komunikasi data.

\section{Sistem Informasi Administrasi Kependudukan dimaksudkan untuk:}

Terselenggaranya dministrasi Kependudukan dalam skala nasional yang terpadu dan tertib, terselenggaranya Administrasi Kependudukan yang bersifat universal, permanen, wajib dan berkelanjutan, terpenuhinya hak penduduk di bidang Administrasi Kependudukan dengan pelayanan yang professional, tersedianya data dan informasi secara nasional mengenai pendaftaran penduduk dan pencatatan sipil pada berbagai tingkatan secara akurat, lengkap, mutakhir, dan mudah diakses sehingga menjadi acuan bagi perumusan kebijakan dan pembangunan pada umumnya.

\section{Komponen Sistem Informasi Administrasi Kependudukan}

Dalam Sistem Informasi Administrasi Kependudukan terdapat 3 komponen yaitu, pendaftaran penduduk, pencatatan sipil dan pengolahan informasi. Dari operasional ketiga komponen tersebut selanjutnya terjabarkan sebagai aktivitas pelayanan kepada masyarakat dan institusi terkait. a). Pendaftaran Penduduk Sarana untuk membangun basis data dan menerbitkan identitasbagi setiap penduduk dewasa dengan mencamtukan Nomor Penduduk sebagai identitas tunggal. Dari kegiatan pendaftaran penduduk ini kemudian diterbitkan 3 dokumen, yaitu: Nomor Induk Kependudukan (NIK), Kartu Keluarga, dan KTP; b). Pencatatan Sipil, Merupakan sarana untuk mencatat peristiwa penting yang dialami penduduk dan perlu dilegalisir oleh negara melalui penerbitan dokumen yang sah menurut hukum dalam bentuk akta catatan sipil. Beberapa peristiwa penting yang harus dilaporkan diantaranya:1). Kelahiran; 2). Kematian; 3). Perkawinan; 4). Perceraian, c). Pengelolaan Informasi Kependudukan Pengelolaan data hasil pendaftaran penduduk dan pencatatan sipil melalui suatu media atau alat yang akan menjadikannya sebagai informasi tentang perkembangan penduduk dari waktu ke waktu.
Karena ouputnya informasi, maka komponen ini sering disebut juga sebagai pengelolaan informasi.

Menurut Peraturan Menteri Dalam Negeri Nomor 25 Tahun 2011 Tentang Pedoman Pengkajian, Pengembangan Dan Pengelolaan Sistem Informasi Administrasi Kependudukan; (1). Pengelola SIAK di pusat paling sedikit, terdiri dari: kepala pusat data dan pusat data pengganti, manager keamana, supervisor aplikasi SIAK, supervisor ajudikasi identifikasi sidik jari, sistem analis, Programmer, administrator database, administrator perangkat keras, administrator jaringan, administrator pelayanan bantuan (help desk), administrator ajudikasi identifikasi sidik jari, ajudikator identifikasi sidik jari, operator, dan teknisi; (2). Pengelola SIAK di provinsi, paling sedikit terdiri dari: kepala pusat data, manager keamanan, supervisor aplikasi SIAK, sistem analis, Programmer, administrator database, administrator perangkat keras, administrator jaringan, operator, teknisi; 3). Pengelola SIAK di kabupaten/kota, paling sedikit terdiri dari: kepala pusat data, manager keamanan, supervisor aplikasi SIAK, sistem analis, Programmer, administrator database kependudukan dan rekaman sidik jari, administrator perangkat keras, administrator jaringan, Operator, dan teknisi.

\section{Pengertian Efektivitas Kerja}

Menurut Azhar Susanto (2004 : 41) bahwa efektivitas artinya informasi harus sesuai dengan kebutuhan pemakai dalam mendukung suatu proses bisnis, termasuk di dalamya informasi tersebut harus disajikan dalam waktu yang tepat, format yang tepat sehingga dapat dipahami, konsisten dengan format sebelumnya, isinya sesuai dengan kebutuhan saat ini dan lengkap atau sesuai dengan kebutuhan dan ketentuan. Sedangkan menurut Zulkifli Amsyah (2003 : 130) bahwa efektivitas adalah kegiatan mulai dengan adanya fakta kegiatan sehingga menjadi data, baik yang berasal dari hubungan dan transaksi internal dan eksternal maupun berasal dari hubungan antar unit dan di dalam unit itu sendiri.

"Efektivitas adalah pemanfaatan sumber daya, sarana dan prasarana dalam jumlah tertentu yang ditetapkan sebelumnya untuk menghasilkan sejumlah barang atas jasa kegiatan yang dijalankannya. Efektivitas menunjukkan keberhasilan dari segi tercapai tidaknya sarana yang telah ditetapkan. Jika hasil kegiatan semakin mendekati sasaran, berarti makin tinggi efektivitasnya” (Siagian, 2007: 24).

Sondang P. Siagian (2000 : 151) berpendapat 
bahwa efektivitas terkait penyelesaian pekerjaan tepat pada waktu yang telah ditetapkan sebelumnya atau dapat dikatakan apakah pelaksanaan sesuatu tercapai sesuai dengan yang direncanakan sebelumnya. Masih menurut Siagian (2000 : 171) efektivitas adalah tercapainya berbagai sasaran yang telah ditentukan sebelumnya tepat pada waktunya dengan menggunakan sumber-sumber tertentu yang sudah dialokasikan untuk melakukan berbagai kegiatan.

Dari pengertian di atas, terdapat beberapa hal yang dapat ditarik kesimpulan dalam unsur efektivitas,yaitu : (1) Pencapaian tujuan, yaitu suatu kegiatan dikatakan efektif apabila dapat mencapai tujuan atau sasaran yang telah ditentukan sebelumnya; (2) Ketepatan waktu, yaitu suatu kegiatan dikatakan efektif apabila penyelesaian atautercapai tujuan sesuai dengan waktu yang telah ditentukan; (3) Manfaat, yaitu suatu kegiatan dikatakan efektif apabila tujuan itu memberikan

\section{Kerangka Pemikiran}

Kerangka Pemikiran merupakan model konseptual tentang bagaimana teori berhubungan dengan berbagai faktor yang telah diidentifikasi manfaat bagi masyarakat setempat sesuai dengan kebutuhannya; 4) Hasil, yaitu suatu kegiatan dikatakan efektif apabila kegiatan tersebut mendatangkan hasil.

Pendekatan Efektivitas S.P Siagan (2002), mengemukakan bahwa efektivitas suatu organisasi dapat diukur dari berbagai hal, yaitu kejelasan tujuan, kejelasan strategi pencapain tujuan, proses analisa dan perumusan kebijakan yang mantap, tersedianya sarana dan prasarana yang efektif dan efisien, sistem pengawasan dan pengendalian yang bersifat mendidik. Ada beberapa kriteria yang dapat digunakan untuk mengukur efektivitas kerja dari organisasi yang memberikan pelayanan, antara lain: (1). Faktor waktu, yaitu ketepatan dan kecepatan waktu dalam menyelesaikan pekerjaan; (2).Faktor kecermatan, disini adalah faktor ketelitian dalam menyelesaikan pekerjaan; (3). Faktor kebiasaan, faktor ini melihat cara dan kebiasaan pegawai dalam menyelesaikan pekerjaan.

sebagai masalah yang penting (Sugiyono, 2008:91). Adapun yang menjadi kerangka pemikiran dalam penelitian ini disusun ke dalam gambar sebagai berikut:

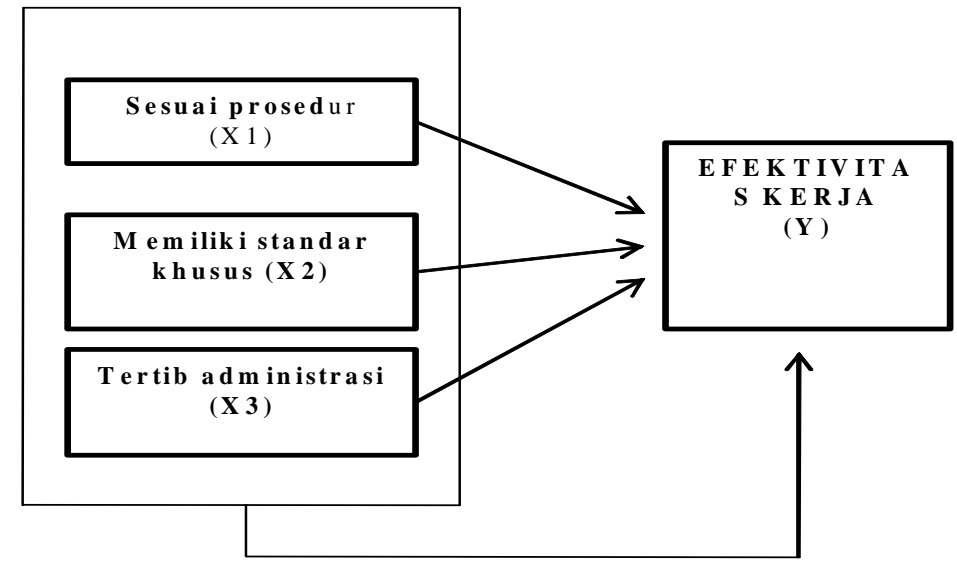

Sumber: (Rahmi Khairunnisak, 2014) (Siagian, 2007)

Gambar 2.1. Kerangka Pemikiran

\section{Hipotesis}

$\mathrm{H}_{1}$ : Terdapat pengaruh yang signifikan secara parsial antara variabel-variabel sistem informasi administrasi kependudukan terhadap efektivitas kerja pegawai pada Kantor Dinas Kependudukan dan Pencatatan Sipil Kabupaten Bogor.

$\mathrm{H}_{2}$ :Terdapat pengaruh yang signifikan secara simultan antara variabel-variabel sistem informasi administrasi kependudukan terhadap efektivitas kerja pegawai pada Kantor Dinas Kependudukan dan Pencatatan Sipil Kabupaten Bogor.

\section{METODE}

Jenis penelitian yang digunakan dalam penelitian ini adalah penelitian asosiatif kausal dengan menggunakan pendekatan kuantitatif. Penelitian asosiatif kausal adalah penelitian yang bertujuan untuk mengetahui pengaruh antara dua variabel atau lebih. Penelitian ini akan menjelaskan antara mempengaruhi dan dipengaruhi dari variabel-variabel yang diteliti (Sugiyono, 2013:11)

Variabel penelitian pada dasarnya adalah segala 
sesuatu yang bebentuk apa saja yang ditetapkan oleh peneliti untuk dipelajari sehingga diperoleh informasi tentang hal tersebut, kemudian ditarik kesimpulan (Sugiyono, 2009:38). Dalam penelitian ini menggunakan dua variabel yaitu: Variabel Terikat (Dependent Variable) dan variabel bebas (Independent variabel)

Penelitian ini dilakukan di Dinas Kependudukan dan Pencatatan Sipil Kabupaten Bogor. Waktu penelitian yaitu selama 6 (enam) bulan yaitu dari bulan April sampai September 2017.Dalam penelitian ini objeknya adalah pegawai yang menggunakan aplikasi sistem informasi administrasi kependudukan

Populasi adalah wilayah generalisasi terdiri atas obyek/subyek yang mempunyai kualitas dan karakteristik tertentu (Sugiyono, 2008:115). Dalam penelitian ini populasinya adalah pegawai yang menggunakan sistem informasi administrasi kependudukan (SIAK) yaitu berjumlah 45 orang. Sampel adalah sebagian dari jumlah dan karakteristik yang dimiliki oleh populasi tersebut (Sugiyono, 2008:116). Adapun jenis sample yang digunakan dalam penelitian ini adalah sampling jenuh. Sampling jenuh adalah teknik penentuan sampel bila seluruh anggota populasi digunakan sebagai sampel (Sugiyono, 2001:61). Dengan demikian sample dalam penelitian ini berjumlah 45 orang pegawai.

\section{Teknik Analisis Data}

Dalam penelitian ini dilakukan uji validasi digunakan untuk mengukur sah atau valid tidaknya suatu kuesioner. Suatu kuesioner dikatakan valid jika pertanyaan pada kuesioner mampu untuk mengungkapkan sesuatu yang akan di ukur oleh kuesioner tersebut (Imam Ghozali, 2005). Untuk menguji validitas dari pertanyaan dengan taraf signifikansi $(\mathrm{a})=0,05$ digunakan rumus koefisien korelasi produk moment dari Karl Pearson. Penelitian ini juga melakukan uji Reliabilitas sebagai alat untuk mengukur suatu kuesioner yang merupakan indikator dari variabel. Suatu kuesioner dikatakan reliabel atau handal jika jawaban seseorang terhadap pertanyaan adalah konsisten atau stabil dari waktu ke waktu (Imam Ghozali, 2005:41)

\section{Uji Asumsi Kasik}

Model regresi linear berganda akan lebih tepat digunakan apabila memenuhi asumsi klasik oleh karenanya pada penelitian ini juga melakukan uji asumsi klasik yang terdiri dari: Uji Normalitas Uji normalitas di maksudkan untuk memperlihatkan bahwa sampel di ambil dari populasi yang berdistribusi normal. Ada beberapa teknik yang dapat digunakan untuk menguji normalitas, antara lain Chikuadrat, Uji Lilliefors dan Uji KolmogorovSmirnov (Joko Sulistyo, 2012:50).

\section{Uji Multikolinieritas}

Uji multikolonieritas bertujuan untuk menguji apakah pada dalam model regresi ditemukan adanya korelasi antar variabel independen. Model regresi yang baik seharusnya tidak mengandung korelasi diantara variabel independen. Jika variabel independen saling berkorelasi maka variabel ini tidak ortogonal. Variabel ortogonal yaitu variabel independen dengan nilai korelasi antar variabel independen $=0$. Untuk mendeteksi adanya multikolonieritas dengan membuat hipotesis:

Tolerance value $<0.10$ atau VIF $>10$ : Terjadi multikolonieritas

Tolerance value $>0.10$ atau $<\mathrm{VIF}<10$ : Tidak terjadi multikolonieritas

\section{Uji Heterokedastisitas}

Uji heterokedastisitas terjadi dalam regresi apabila varian eror tidak konstan untuk beberapa nilai $\mathrm{X}$, pendeteksian konstan tidaknya varian eror dapat dilakukan dengan menggambar grafik antar $\mathrm{Y}$ dengan residu. Apabila garis yang membatasi sebaran titik relatif pararel maka varian eror dikatakan konstan. (Joko Sulistyo, 2012:60) Analisa Korelasi, digunakan untuk mengetahui apakah ada hubungan antara dua variabel. Tujuan analisa ini untuk mengetahui tingkat hubungan variabel $X$ yaitu sistem informasi administrasi kependudukan (SIAK) dengan variabel Y yaitu efektivitas kerja. Teknik korelasi yang digunakan adalah teknik korelasi product moment dari pearson.

\section{Regresi Linier Berganda}

Untuk mengetahui seberapa besar pengaruh variabel bebas $(\mathrm{X})$ terhadap variabel terikat $(\mathrm{Y})$ : Rumus : $\mathrm{Y}=\alpha+\mathrm{b}_{1} \mathrm{X}_{1}+\mathrm{b}_{2} \mathrm{X}_{2}+\mathrm{b}_{3} \mathrm{X}_{3}$

\section{Pengujian Hipotesis}

pada pengujian hipotesis digunakan uji hipotesis secara parsial (uji t) untuk menguji tingkat signifikan pengaruh variabel-variabel bebas terhadap variabel terikat secara terpisah (parsial). Dalam penelitian ini digunakan juga uji $\mathrm{F}$ untuk mengetahui tingkat signifikansi pengaruh variabel-variabel independen (sesuai prosedur, memiliki standar khusus, dan tertib administrasi) secara bersama-sama (simultan) terhadap variabel dependen (efektivitas kerja pegawai). Koefisien Determinasi Koefisien 
determinasi pada intinya mengukur seberapa jauh kemampuan model dalam menerangkan variasi variabel dependen. Nilai koefisien determinasi adalah antara 0 dan satu, nilai koefisien determinasi kecil, berarti kemampuan variabel-variabel independen dalam menjelaskan variasi variabel-variabel dependen sangat terbatas. Nilai koefisien determinasi mendekati satu, berarti kemampuan variabel-variabel independen memberikan hampir semua informasi yang di butuhkan untuk memprediksi variasi variabelvariabel dependen (Ghozali, 2005:83). Adapun rumus Koefisien Determinasi adalah: KD $=\mathrm{r}^{2}$ x 100\%.

\section{HASIL DAN PEMBAHASAN}

\section{Gambaran Umum}

Dinas Kependudukan dan Pencatatan Sipil Kabupaten Bogor dibentuk berdasarkan Peraturan Daerah Kabupaten Bogor Nomor 11 tahun 2008, tentang Pembentukkan Organisasi dan Tata Kerja Dinas Kependudukan dan Pencatatan Sipil Kabupaten Bogor. Dinas Kependudukan dan Kantor Catatan Sipil semula adalah dua entitas yang terpisah. Dinas Kependudukan adalah Perangkat Daerah Kabupaten Bogor, sedangkan Kantor Catatan Sipil merupakan instansi vertikal Departemen Dalam Negeri.

Dinas Kependudukan dan Pencatatan Sipil Kabupaten Bogor dibentuk berdasarkan Peraturan Daerah Kabupaten Bogor Nomor 11 tahun 2008, tentang Pembentukan Dinas Daerah. Dinas Kependudukan dan Pencatatan Sipil mempunyai tugas pokok membantu Bupati melaksanakan urusan pemerintahan daerah berdasarkan asas otonomi di bidang kependudukan dan Pencatatan sipil serta tugas-tugas pembantuan lainnya.

\section{Karakteristik Responden}

Jumlah responden berdasarkan usia bahwa responden berdasarkan usia terbanyak adalah pada usia 20-25 tahun sebesar 16 orang (48,9\%), urutan kedua pada usia 25-30 tahun sebesar 15 orang (31,1\%), urutan ketiga pada usia 30-35 tahun sebesar 7 orang $(17,8 \%)$, dan urutan keempat pada usia e”
35 tahun sebesar 7 orang (2,2\%). Oleh karena itu, dapat disimpulkan bahwa responden tersebut adalah para pegawai yang menggunakan SIAK adalah pegawai muda. Usia tersebut dipandang memiliki potensi untuk mengoperasikan SIAK dan masih bersemangat secara aktif sehingga lebih cepat dalam mengoperasikan sistem.

Berdasarkan jenis kelamin dapat diketahui bahwa responden terbanyak adalah laki-laki yaitu 24 orang (53,3\%), sedangkan perempuan hanya 21 orang (46,7\%). Hal ini menunjukkan bahwa laki-laki sebagai mayoritas pengguna aplikasi sistem informasi administrasi kependudukan (SIAK).

Berdasarkan data diatas dapat dilihat bahwa tingkat pendidikan responden terbanyak adalah Sarjana (S1) sejumlah 20 orang (44,5\%), urutan kedua pada SMA/SMK sejumlah 15 orang (33,3\%), urutan ketiga pada pendidikan D3 sejumlah 8 orang $(17,8 \%)$, dan urutan keempat pada pendidikan S2 sejumlah 2 orang (4,4\%). Dari data diatas dapat disimpulkan, bahwa sebagian besar pegawai yang menggunakan aplikasi sistem informasi administrasi kependudukan (SIAK) di Dinas Kependudukan dan Pencatatan Sipil Kabupaten Bogor berpendidikan terakhir Sarjana.

\section{Analisis Data dan Pembahasan}

Uji validitas pada penelitian ini menggunakan korelasi person, yang dilakukan dengan menghitung korelasi antara skor masing-masing butir pertanyaan dengan skor total variabel. Hasil uji validitas dalam penelitian ini menunjukkan hasil dimana pada indikator dianalisis, dengan menggunakan $r$ tabel sebesar 0,2940. Seluruh item pertanyaan yang bejumlah 12 menunjukan hasil yang valid dikarenakan r hitung $>$ dari pada $r$ tabel. Tercatat $r$ hitung terkecil 0,494 untuk pertanyaan no.2 dan $r$ hitung terbesar adalah 0,864 pada pertanyaan no.3. Probabilitas kesalahan (sig) dari masing masing indikator seluruhnya dibawah 0,05. Dapat disimpulkan bahwa semua pertanyaan dalam kuesioner penelitian ini adalah valid.

Tabel 1. Hasil Uji Reliabilitas

\begin{tabular}{lccc}
\hline \multicolumn{1}{c}{ Variabel } & Cronbach's Alpha & Alpha & Keterangan \\
\hline Sesuai Prosedur (X1) & 0,813 & 0,6 & Reliabel \\
\hline $\begin{array}{l}\text { Memiliki Standar Khusus } \\
\text { (X2) }\end{array}$ & 0,799 & 0,6 & Reliabel \\
\hline Tertib Administrasi (X3) & 0,781 & 0,6 & Reliabel \\
\hline Efektivitas Kerja (Y) & 0,759 & 0,6 & Reliabel \\
\hline
\end{tabular}

Sumber: Data primer yang diolah, 2017 
Dari data dari tabel 1 diatas, terlihat nilai Cronbach's Alpha variabel sesuai prosedur sebesar 0,813 , variabel standar khusus sebesar 0,799, variabel tertib administrasi sebesar 0,781, dan variabel

\section{Uji Asumsi Klasik \\ Uji Normalitas}

Berdasarkan scatterplot pada gambar 1 dibawah ini, dapat dilihat bahwa data dalam penelitian memiliki distribusi yang normal karena penyebaran data disekitar garis diagonal dan mengikuti arah garis efektivitas kerja sebesar 0,759. Yang berarti nilai Cronbach's Alpha dari semua variabel yang diuji lebih besar dari Cronbach's Alpha 0,6. Dapat disimpulkan bahwa semua variabel adalah reliabel.

diagonal, maka dapat dikatakan bahwa data tersebut berdistribusi normal, dengan demikian bahwa model regresi yang digunakan layak untuk digunakan.

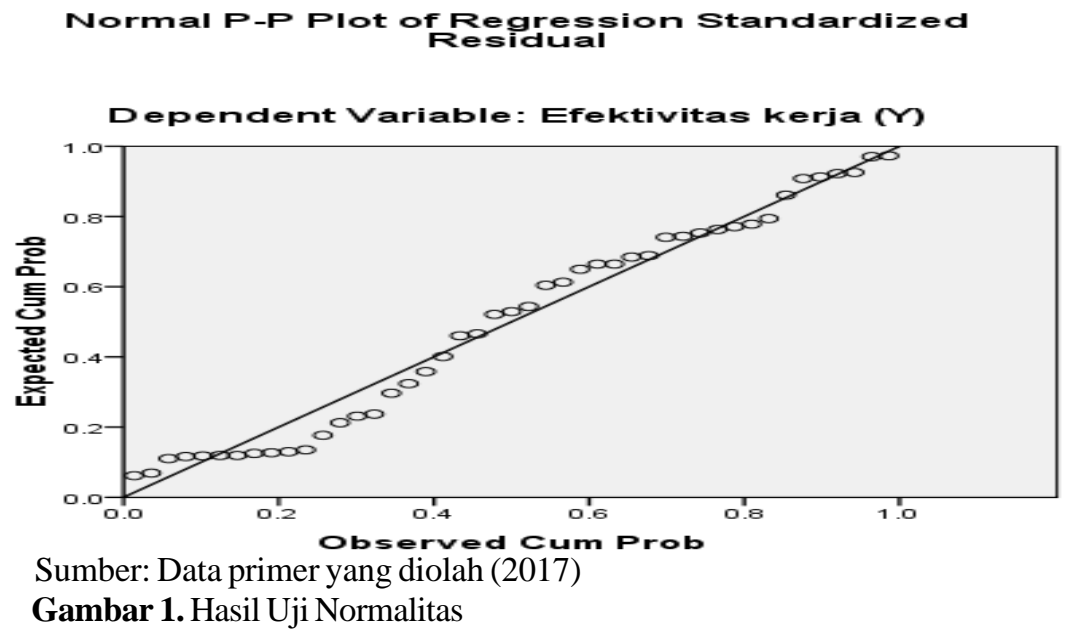

Tabel 2. Hasil Uji Multikolonieritas

\begin{tabular}{lccc}
\hline \multicolumn{1}{c}{ M odel } & $\begin{array}{c}\text { Collonearity Statistics } \\
\text { Tolerance }\end{array}$ & VIF & Keterangan \\
\hline Sesuai Prosedur (X1) & 0,612 & 1,633 & Tidak Terjadi Multikolonieritas \\
\hline $\begin{array}{l}\text { Memiliki Standar } \\
\text { Khusus (X2) }\end{array}$ & 0,342 & 2,928 & Tidak Terjadi Multikolonieritas \\
\hline Tertib Administrasi (X3) & 0,352 & 2,842 & Tidak Terjadi Multikolonieritas \\
\hline
\end{tabular}

Sumber: Data Primer yang diolah (2017)

Dari tabel 2 tersebut menunjukkan bahwa nilai model regresi tidak mengalami gangguan multikolonieritas. Hal ini menunjukkan nilai tolerance semua variabel bebas tidak ada yang nilainya kurang dari 0,10. Sementara perhitungan nilai VIF menunjukkan tidak ada variabel bebas yang memiliki nilai lebih dari 10. Sehingga dapat disimpulkan bahwa model regresi yang dihasilkan tidak terjadi gejala multikolonieritas.

Scatterplot

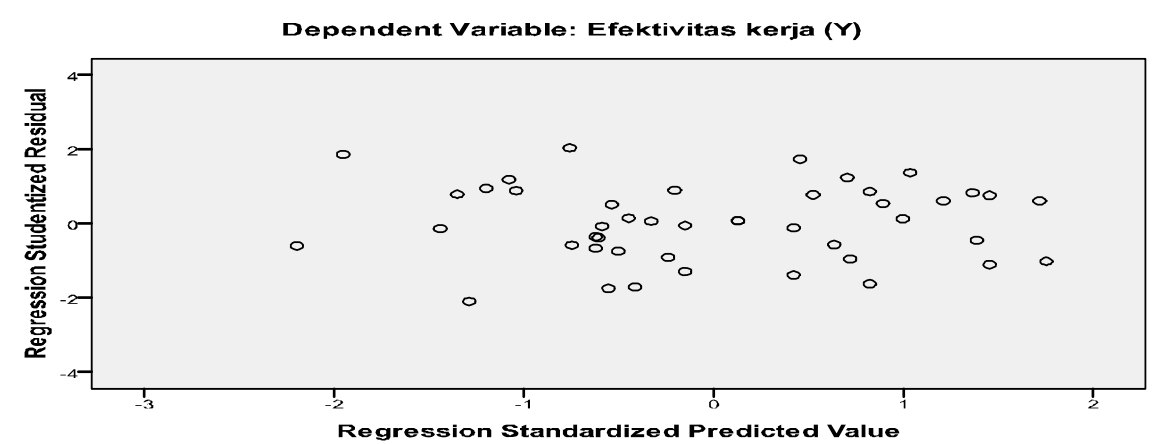

Gambar 2. Hasil Uji Heteroskedastisitas

Sumber: Data primer yang diolah (2017) 
Pada gambar 2 diatas terlihat bahwa titik-titik menyebar diatas dan dibawah angka nol pada sumbu $\mathrm{Y}$ dan tidak membentuk pola tertemtu. Sesuai dengan pedoman uji heteroskedastisitas, maka dalam penelitian ini tidak terjadi heteroskedastisitas atau disebut homokedastisitas. Hal ini dibuktikan dengan garfik plot diata yang tidak membentuk pola tertentu yang teratur sehingga penelitian ini layak dilakukan atau dilanjutkan.

\section{Analisis Korelasi}

Berdasarkan uji korelasi diatas diperoleh nilai korelasi untuk variabel sesuai prosedur sebesar 0,497 yang berarti sedang, variabel memiliki standar khusus sebesar 0,572 berarti sedang, variabel tertib administrasi sebesar 0,503 yang juga berarti sedang.

\section{Analisis Regresi Linear Berganda}

Tabel 3. Hasil Uji Regresi Linear Berganda Coefficients $^{\mathrm{a}}$

\begin{tabular}{|c|c|c|c|c|c|c|c|}
\hline \multirow[t]{2}{*}{ Model } & \multicolumn{2}{|c|}{$\begin{array}{l}\text { Unstandardized } \\
\text { Coefficients }\end{array}$} & \multirow{2}{*}{$\begin{array}{c}\text { Standardized } \\
\text { Coefficients } \\
\text { Beta }\end{array}$} & \multirow[b]{2}{*}{$\mathrm{T}$} & \multirow[b]{2}{*}{ Sig. } & \multicolumn{2}{|c|}{$\begin{array}{l}\text { Collinearity } \\
\text { Statistics }\end{array}$} \\
\hline & B & Std. Error & & & & Tolerance & VIF \\
\hline 1 (Constant) & 23.000 & 5.904 & \multicolumn{5}{|c|}{3.896 .000} \\
\hline sesuaiprosedur (X1) & .633 & .436 & \multicolumn{3}{|c|}{.2311 .454 .153} & .612 & 1.633 \\
\hline $\begin{array}{l}\text { memilikistandarkhusus } \\
\text { (X2) }\end{array}$ & .756 & .422 & \multicolumn{3}{|c|}{.381 1.793 .080} & .342 & 2.928 \\
\hline Tertibadministrasi (X3) & .152 & .481 & \multicolumn{3}{|c|}{$\begin{array}{lll}.066 & .316 .753\end{array}$} & .352 & 2.842 \\
\hline
\end{tabular}

a. Dependent Variable: Efektivitaskerja (Y)

Sumber: Data primer yang diolah (2017)

Berdasarkan Tabel 3 hasil uji regresi linear berganda untuk diatas diperoleh persamaan regresi yaitu:

$$
\mathrm{Y}=23,000+0,633 \mathrm{X} 1+0,756 \mathrm{X} 2+0.152 \mathrm{X} 3
$$

Nilai koefisien regresi dari variabel diatas menunjukkan besarnya pengaruh variabel bebas (X) terhadap variabel terikat (Y). Semakin besar nilai pada koefisien variabel bebas (X) maka semakin besar pula pengaruhnya terhadap variabel terikat (Y). Dari model regresi tersebut dapat dijabarkan sebagai berikut: (1) Nilai konstanta sebesar 23,000, menyatakan bahwa jika variabel sesuai prosedur $\left(\mathrm{X}_{1}\right)$, memiliki standar khusus $\left(\mathrm{X}_{2}\right)$, dan tertib administrasi $\left(\mathrm{X}_{3}\right)$ dianggap konstan, maka efektivitas kerja (Y) akan meningkat sebesar 23,000; (2)
Koefisien regresi variabel sesuai prosedur $\left(\mathrm{X}_{1}\right)$ sebesar 0,633 dengan tanda positif, menyatakan bahwa setiap kenaikkan satu satuan dari sesuai prosedur, maka nilai Y (efektivitas kerja) akan meningkat sebesar 0,633; (3) Koefisien regresi variabel memiliki standar khusus (X2) sebesar 0,756 dengan tanda positif, menyatakan bahwa setiap kenaikkan satu satuan dari memiliki standar khusus, maka nilai Y (efektivitas kerja) akan meningkat sebesar 0,756; (4) Koefisien regresi variabel tertib administrasi $\left(\mathrm{X}_{3}\right)$ sebesar 0,152 dengan tanda positif, menyatakan bahwa setiap kenaikkan satu satuan dari tertib administrasi, maka nilai Y (efektivitas kerja) akan meningkat sebesar 0,152.

Tabel 4. Hasil Uji T

Coefficients ${ }^{a}$

\begin{tabular}{|c|c|c|c|c|c|c|}
\hline \multirow{2}{*}{ Model } & \multicolumn{4}{|c|}{ Unstandardized Coefficients Standardized Coefficients } & \multirow[b]{2}{*}{$\mathrm{t}$} & \multirow[b]{2}{*}{ Sig. } \\
\hline & B & Std. Error & Beta & & & \\
\hline 1 (Constant) & 23.000 & 5.904 & & & 3.896 & .000 \\
\hline sesuai prosedur (X1) & .633 & .436 & & .231 & 1.454 & .153 \\
\hline
\end{tabular}

\section{Uji Hipotesis}

\section{Uji T (Uji Parsial)}

Tabel 4. Uji T adalah uji hipotesis secara parsial dimaksudkan, untuk mengetahui tingkat signifikans pengaruh variabel independen terhadap variabel dependen secara terpisah (parsial) dikaitkan dengan hipotesis yang diajukan. 
Lanjutan Tabel 4. Hasil Uji T

Coefficients $^{\mathrm{a}}$

\begin{tabular}{lccccc}
\hline \multicolumn{2}{c}{ Model } & \multicolumn{3}{c}{ Unstandardized Coefficients Standardized Coefficients } & \\
& B & Std. Error & Beta & t & Sig. \\
\hline memiliki standar khusus $(\mathrm{X} 2)$ & .756 & .422 & .381 & 1.793 .080 \\
\hline Tertib administrasi $(\mathrm{X} 3)$ & .152 & .481 & .066 & .316 .753 \\
\hline
\end{tabular}

a. Dependent Variable: Efektivitas kerja $(\mathrm{Y})$

Sumber: Data primer yang diolah (2017)

Tabel 4 diatas memperlihatkan hasil uji t dengan penjelasan sebagai berikut: (1) Hasil Uji Signifikansi Variabel Sesuai Prosedur (X1). Terlihat bahwa T hitung sesuai prosedur adalah 1,454 sedangkan $\mathrm{T}$ tabel bisa dihitung pada tabel t-test, dengan $\alpha=0,05$ atau $5 \%$ dan $\mathrm{df}=41$ (didapat dari rumus $\mathrm{n}-\mathrm{k}-1=45-3-1=41$ ). Didapat $\mathrm{T}$ tabel sebesar 2,019. Variabel sesuai prosedur memiliki nilai signifikan dari hasil Uji t $(0,153>0,05)$ artinya tidak signifikan, sedangkan $\mathrm{T}$ hitung $<\mathrm{T}$ tabel $(1,454<$ 2,019), maka Ho diterima dan Ha ditolak, sehingga dapat disimpulkan tidak terdapat pengaruh yang signifikan antara variabel sesuai prosedur terhadap efektivitas kerja; (2) Hasil Uji Signifikansi Variabel Memiliki Standar Khusus (X2). Terlihat bahwa T hitung memiliki standar khusus adalah 1,793 sedangkan $\mathrm{T}$ tabel bisa dihitung pada tabel t-test, dengan á $=0,05$ atau $5 \%$ dan $\mathrm{df}=41$ (didapat dari rumus $n-k-1=45-3-1=41$ ). Didapat $T$ tabel sebesar 2,019. Variabel memiliki standar khusus memiliki nilai signifikan dari hasil Uji t $(0,080>0,05)$ artinya tidak signifikan, sedangkan $\mathrm{T}$ hitung $<\mathrm{T}$ tabel ( $1,793<2,019)$, maka $\mathrm{H}_{\mathrm{O}}$ diterima dan $\mathrm{H}_{\mathrm{a}}$ ditolak, sehingga dapat disimpulkan tidak terdapat pengaruh yang signifikan antara variabel memiliki standar khusus terhadap efektivitas kerja; (3) Hasil Uji Signifikansi Variabel Tertib Administrasi (X3). Terlihat bahwa $\mathrm{T}$ hitung tertib administrasi adalah 0,316 sedangkan $\mathrm{T}$ tabel bisa dihitung pada tabel ttest, dengan $=0,05$ atau $5 \%$ dan $\mathrm{df}=41$ (didapat dari rumus $\mathrm{n}-\mathrm{k}-1=45-3-1=41$ ). Didapat $\mathrm{T}$ tabel sebesar 2,019. Variabel tertib administrasi memiliki nilai signifikan dari hasil Uji t $(0,753>0,05)$ artinya tidak signifikan, sedangkan $\mathrm{T}$ hitung $<\mathrm{T}$ tabel $(0,316<2,019)$, maka $\mathrm{H}_{\mathrm{O}}$ diterima dan $\mathrm{H}_{\mathrm{a}}$ ditolak, sehingga dapat disimpulkan tidak terdapat pengaruh yang signifikan antara variabel tertib administrasi terhadap efektivitas kerja.

\section{Uji F (Uji Simultan)}

Tabel 5. Hasil Uji F

A N O $x^{\prime} \mathbf{A}^{\text {b }}$

\begin{tabular}{|c|c|c|c|c|c|c|c|}
\hline & Model & S u m & of Squares & $\mathrm{Df}$ & M ean Square & $\mathrm{F}$ & S ig. \\
\hline \multirow{3}{*}{1} & Regression & & 377.261 & 3 & 125.754 & 7.902 & $.000^{\mathrm{a}}$ \\
\hline & $\underline{\text { Residual }}$ & & 652.517 & 41 & 15.915 & & \\
\hline & Total & & 1029.778 & 44 & & & \\
\hline
\end{tabular}

a. Predictors: (Constant), Tertib administrasi (X 3), sesuai prosedur (X1), m em iliki standar khusus (X 2 )

b. Dependent Variable: E fektivitas kerja (Y)

Sumber: Data primer yang diolah (2017)

Dari tabel 5 diatas dapat disimpulkan bahwa hasil perhitungan statistik menunjukkan bahwa nilai $\mathrm{F}$ hitung =7,902 dengan signifikan sebesar 0,000 <0,05. Nilai $\mathrm{F}$ tabel dengan $\mathrm{df}=\mathrm{n}-\mathrm{k}, \mathrm{df}=45-4=41$ diperoleh sebesar 2.83. Dengan demikian $\mathrm{f}$ hitung lebih besar dari $\mathrm{f}$ tabel $(7,902>2,83)$. Maka $\mathrm{H}_{\mathrm{O}}$ ditolak dan $\mathrm{H}_{\mathrm{a}}$ diterima, artinya bahwa secara simultan variabel sesuai prosedur, memiliki standar khusus, dan tertib administrasi mempunyai pengaruh yang signifikan terhadap efektivitas kerja.

\section{Uji Koefisien Determinasi}

Tabel 6. Hasil Uji Koefisien Determinasi M odel S u m m a ry

\begin{tabular}{|l|c|c|c|c|c|}
\hline & & & & \\
M odel & R & R Square & Adjusted R Square & Std. Error of the Estimate & Durbin-W atson \\
\hline 1 & $.605^{\mathrm{a}}$ & .366 & .320 & 3.989 & 1.397 \\
\hline
\end{tabular}

b. Dependent V ariable: E fektivitaskerja (Y)

Sumber: Data primer yang diolah (2017) 
Dari tabel 6 diatas didapat nilai Adjusted R Square sebesar 0,320 (32\%), ini menunjukkan bahwa dengan menggunakan model regresi yang didapat dimana variabel independen (sesuai prosedur, memiliki standar khusus, dan tertib administrasi) memiliki pengaruh terhadap variabel dependen sebesar $32 \%$. Sedangkan sisanya 68\% dipengaruhi oleh faktor lain yang tidak diteliti dalam penelitian ini.

\section{SIMPULAN DAN SARAN}

\section{Kesimpulan}

Berdasarkan pada hasil penelitian dan pembahasan mengenai analisis pengaruh sistem informasi administrasi kependudukan (SIAK) terhadap efektivitas kerja pegawai, maka penulis dapat menarik beberapa kesimpulan sebagai berikut:

1. Hasil uji t secara terpisah ( parsial) tidak ada satupun dari ketiga variabel independent $\left(\mathrm{X}_{1}\right.$, $\left.\mathrm{X}_{2}, \mathrm{X}_{3}\right)$ yang berpengaruh terhadap variabel dependen ( $\mathrm{Y}$ ) dimana $\mathrm{T}$ tabel $<$ dari $\mathrm{T}$ hitung, dengan demikian $\mathrm{H}_{\mathrm{O}}$ diterima dan $\mathrm{H}_{\mathrm{a}}$ ditolak. Sedangkan pengujian secara simultan melalui uji F kesemua variabel bebas secara bersama-sama (simultan) berpengaruh terhadap variabel terikat, Ini dapat dibuktikan dengan nilai $\mathrm{F}$ hitung yang lebih besar dari $\mathrm{F}$ tabel $(7,902>2,83)$ dengan nilai signifikan 0,000 yang lebih kecil dari 0,05.

2. Berdasarkan hasil uji regresi liniear berganda, semua variabel menunjukkan hasil yang positif dan variabel memiliki standar khusus $\left(\mathrm{X}_{2}\right)$ merupakan variabel yang mempunyai nilai paling tinggi dibandingkan dengan nilai variabel bebas lainnya, dengan koefisien regresi sebesar 0,756.

3. Sedangkan hasil uji determinasi menunjukkan hasil kemampuan model hanya mempunyai pengaruh sebesar 32\% sisanya sebanyak $68 \%$ dipengaruhi oleh variabel lain yang tidak diteliti dalam penelitian ini.

Saran :

Kemampuan model menggambarkan dalam penelitian ini hanya $32 \%$ ini menjelaskan, bahwa harus ada beberapa variabel, indikator atau dimensi dimensi lain yang perlu ditambahkan atau dimodifikasi dalam penelitian selanjutnya, sehingga asumsi/hipotesis utama dalam penelitian ini dapat tergambarkan dengan lebih baik.

\section{DAFTAR PUSTAKA}

Amsyah, Zulkifli. 2003. Manajemen Sistem Informasi. PT. Gramedia Pustaka Utama : Jakarta.
Ghozali, Imam. 2005. Aplikasi Multivariate dengan Program SPSS. Badan Penerbit Universitas Diponegoro : Semarang.

Hadayaningrat, Soewarno. 1999. Pengantar Studi Ilmu Administrasi danManajemen. Gunung Agung. Jakarta.

Hadi, Sutrisno. 2004 . Metodologi Research, Andi Yogyakarta: Yogyakarta.

Khairunnisak, Rahmi. 2014. Pengaruh Sistem Informasi Administrasi Kependudukan Terhadap Efektivitas Kerja Pegawai Pada Kantor Dinas Pencatatan Sipil Kabupaten Aceh Utara.

Manullang. 2007. Manajemen Personalia. Gajah Mada University Press : Yogyakarta.

Nugraha, Rizky. 2014. Analisis Rancangan SIAK Sebagai Pengembangan Egovernment Menuju Good Governance.

Siagian, Sondang. P. 2002. Manajemen Sumber Daya Manusia. Bumi Aksara : Jakarta.

Siagian, Sondang. P. 2000. Organisasi, Kepemimpinan dan PerilakuAdministrasi. Gunung Agung : Jakarta.

Siagian, Sondang. P. 2007. Teori Pengembangan Organisasi. Bumi Aksara :Jakarta.

Singarimbun, Masri dan Sofyan Effendi. 2008. Metode Penelitian Survei. LP3S : Jakarta.

Sugiyono. 2007. Statistika Untuk Penelitian.Alfabeta : Bandung

Sugiyono. 2008. Metode Penelitian Kuantitatif, Kualitatif dan R\&D.Alfabeta : Bandung.

Sugiyono. 2009. Metode Penelitian Administrasi dilengkapi metode R\&D. Alfabeta : Bandung.

Sugiyono. 2013. Metode Penelitian Kuantitatif, Kualitatif dan R\&D. Alfabeta : Bandung.

Sulistyo, Joko. 2012. 6 Hari Jago SPSS. Jakarta.

Susanto, Azhar. 2004. Sistem Informasi Manajemen Konsep dan Pengembangannya. Lingga Jaya : Bandung.

Syafariani, Fenny. 2012. Peranan Dari Penerapan Program Aplikasi Sistem Informasi Administrasi Kependudukan (SIAK) Terhadap Kepuasan Pegawai (User) Di Kantor Kecamatan Kabupaten Bandung.

\section{Dokumen :}

Peraturan Pemerintah Nomor 37 Tahun 2007 tentang Pelaksanaan Undang-Undang Nomor 23 Tahun 2006 tentang Administrasi Kependudukan.

Peraturan Pemerintah Republik Indonesia Nomor 102 Tahun 2012 tentang Perubahan atas Peraturan Pemerintah Nomor 37 Tahun 2007 tentang Pelaksanaan Undang-Undang Nomor 23 Tahun 2006 tentang Administrasi Kependudukan.

Undang-Undang Nomor 24 Tahun 2013 Tentang Perubahan Atas Undang-Undang 23 Tahun 2006 Tentang Administrasi Kependudukan.

Peraturan Menteri Dalam Negeri Nomor 25 Tahun 2011 Tentang Pedoman Pengkajian, Pengembangan Dan Pengelolaan Sistem Informasi Administrasi Kependudukan 